\title{
PUBLIC MANAGEMENT
}

DOI https://doi.org/10.51647/kelm.2020.7.1.29

\section{FORESIGHT-TECHNOLOGIA W KSZTALTOWANIU PUBLICZNEJ POLITYKI MEDYCZNEJ}

\author{
Inna Voshko \\ magister administracji publicznej i administracji, aspirant Klasycznego Uniwersytetu Prywatnego \\ (Zaporoże, Ukraina) \\ ORCID ID: 0000-0002-4939-4018 \\ e-mail: Inna_Voshko444@gmail.com
}

\begin{abstract}
Adnotacja. Omówiono kluczowe problemy reformy systemu opieki zdrowotnej na Ukrainie. Ustalono, że głównym czynnikiem oporu jest brak Publicznej Polityki Medycznej. Aby stworzyć wizerunek jej koncepcji, zaproponowano zastosowanie czteroetapowej technologii foresight. Realizuje funkcje: kreatywność, ekspertyza, interakcja i wiarygodność; zapewnia kształtowanie wizerunku polityki w warunkach niepewności. Aby zmniejszyć poziom niepewności, koncepcja polityki jest podzielona na 6 głównych elementów. Jej struktura opiera się na zrozumieniu współczesnej wiedzy na temat opartej na dowodach polityki publicznej, reform rządowych, innowacji społecznych, działalności innowacyjnej w administracji publicznej. Aby wypełnić treść ich wizerunków, zaproponowano przeprowadzenie 6 foresight-badań. Połączenie ich wyników powinno stanowić ogólny wizerunek koncepcji Publicznej Polityki Medycznej. Oparte na dowodach (siódme) badanie foresight powinno potwierdzić wiarygodność uzyskanego wizerunku koncepcji.

Słowa kluczowe: polityka, państwo, ochrona zdrowia, reforma, polityka medyczna, foresight, metodologia, badania, funkcja, etap, faza.
\end{abstract}

\section{FORSITE TECHNOLOGY IN THE FORMATION OF STATE MEDICAL POLICY}

\author{
Inna Voshko \\ Master in Public Management and Administration, \\ Postgraduate Student \\ Classical Private University (Zaporizhzhya, Ukraine) \\ ORCID ID: 0000-0002-4939-4018 \\ e-mail: Inna_Voshko444@gmail.com
}

\begin{abstract}
The key problems of health care reform in Ukraine are considered. It is determined that the main factor of resistance to reforms is the absence of the State Medical Policy. To form the framework of its concept, it is proposed to use four-stage foresight technology. It implements the following functions: creativity, expertise, interaction and credibility; provides the formation of the politics framework under uncertainty. To reduce the level of uncertainty, the policy concept is divided into 6 main components. Its structuring is based on the understanding of modern knowledge about evidencebased public policy, government reforms, social innovations, novals in public administration. To fill their frameworks with the content, it is proposed to conduct 6 foresight studies. The combination of their results should form the general framework of the concept of the State medical policy. Evidence-based (seventh) foresight study should confirm the validity of the obtained framework of the concept.
\end{abstract}

Key words: policy, state, health care, reform, medical policy, foresight, methodology, research, function, stage, phase.

\section{ФОРСАЙТ-ТЕХНОЛОГІЯ У ФОРМУВАННІ ДЕРЖАВНОЇ МЕДИЧНОЇ ПОЛІТИКИ}

\author{
Інна Вошко \\ магістр публічного управління та адміністрування, \\ аспірант \\ Класичного приватного університету (Запоріжжя, Україна) \\ ORCID ID: 0000-0002-4939-4018 \\ e-mail: Inna_Voshko444@gmail.com
}

Анотація. Розглянуто ключові проблеми реформування системи охорони здоров’я в Україні. Визначено, що головним фактором спротиву є відсутність Державної медичної політики. Для формування образу ії концепції запропоновано застосувати чотириетапну форсайт-технологію. Вона реалізує такі функції: креативність, експертиза, взаємодія і достовірність; забезпечує формування образу політики в умовах невизначеності. Для зменшення 
рівня невизначеності концепцію політики поділено на 6 основних складників. Її структурування засноване на розумінні сучасних знань про доказову державну політику, урядові реформи, соціальні інновації, інноваційну діяльність у публічному управлінні. Для наповнення змістом їхніх образів запропоновано проведення 6 форсайтдосліджень. Поєднання їхніх результатів має сформувати загальний образ концепції Державної медичної політики. Доказове (сьоме) форсайт-дослідження має підтвердити достовірність отриманого образу концепції.

Ключові слова: політика, держава, охорона здоров'я, реформа, медична політика, форсайт, методологія, дослідження, функція, етап, стадія.

Вступ. Медична політика держави в Україні (далі - МПД) є однією з головних у забезпеченні належного збереження, функціонування і розвитку суспільства, функцій і завдань держави щодо їі формування і реалізації на засадах кращого світового досвіду. Аналіз основних нормативно-правових актів (Вошко, 2020: 334) свідчить, що засади цієї політики були ще у 1992 р. в Законі України «Основи законодавства України про охорону здоров'я» (далі - Основи законодавства), потім були актуалізовані у 2000 р. в Концепції розвитку охорони здоров'я (далі - О3), у 2015 р. - у Стратегії сталого розвитку «Україна 2020», у 2019 р. - у невідкладних заходах із проведення реформ тощо. За часів незалежності України отримано певні результати реформи системи охорони здоров'я (далі - СОЗ). Однак шлях їі втілення є стриманим: до 2000 р. жодних зрушень; лише у 2018 р. упроваджено первинну медичну допомогу (далі - МД); відставання від інших країн СНД становить майже 20 років; горизонт цілісного їі впровадження є віддаленим, хоча загальне структурноорганізаційне і функціональне бачення нової СО3 за видами МД було офіційно визначено ст. ст. 33 , 35 , $35^{1-4}$ Основ законодавства.

Аналіз останніх досліджень і публікацій (Вошко, 2020: 334) свідчить, що проблеми реформування О3 зумовлені наявністю політичного спротиву, відсутністю належної мотивації впроваджувачів, прогалинами в кадровому, фінансовому, нормативно-правовому, інформаційно-роз'яснювальному забезпеченні тощо. I головне: механізм формування і реалізації державної політики О3 (ст.ст. 13, 14 Основ законодавства) принципово суперечить єдиним засадам державного механізму управління політикою держави; програмноцільове реформування СО3 виявилося неефективним в умовах невизначеностей, що характерно для цієї реформи; відсутня цілісна офіційно затверджена Державна медична політика і Стратегія ії реалізації. Попередньо автором запропоновано орієнтовну структуру МПД (Вошко, 2020: 334).

Основна частина. Мета статmi полягає в розробці концептуального підходу до змістовного наповнення образу медичної політики держави на засадах новітніх знань.

Завдання щодо досягнення цієї мети полягає в обгрунтуванні методології, спроможної забезпечити змістовне наповнення образу МПД в умовах невизначеності за використанням новітніх знань. У дослідженні використано визнані наукові напрацювання, методи аналізу, узагальнення, систематизації і моделювання.

Результати та їх обговорення. Незалежна Україна, орієнтуючись на світовий досвід, останнім часом поступово реформує СОЗ переважно шляхом спроб і помилок, накопичення досвіду і його реалізації. Проте нині в аспекті поставленої мети цієї статті цілком доцільно поставити питання: якщо реформа СО3 вже на шляху втілення, то чи є необхідність нині розробляти МПд? Відповідь: по-перше, взагалі МПД має бути завжди, слугувати дорожньою картою, орієнтиром для теперішніх і наступних дій, постійно і своєчасно оновлюватися, що й передбачено законодавством України; по-друге, не менш важливе питання, якому офіційному задуму відповідає те, що вже втілено і що планується досягти, якщо відсутній обгрунтований і унормований образ нової СО3? Його відсутність, безумовно, є головним джерелом невизначеностей, основним фактором стримування реформи СОЗ загалом. Тобто конструювання нового відбувається без генерального плану перебудови традиційного. 3 огляду на це дійсно необхідно терміново розробити і затвердити не на сьогодні МПД, а СОЗ у віддаленій перспективі. Усвідомлення суспільством їі суті і переваг є найвагомішою передумовою успішності медичної реформи.

У межах політичного процесу (Вошко, 2020: 334) розробка і реалізація образу МПД здійснюються в умовах невизначеності. Тому цей процес має обов'язково супроводжуватися належною методологією, яка заснована на нових знаннях про форсайт-технологію (далі - ФТ) у публічному управлінні (далі - ПУ) (Квітка, 2018: 70), доказову політику держави (Дослідження державних політик..., 2018: 245), медичну політику (Вошко, 2020: 334), урядові реформи (Кравченко, 2008: 296), теорію, методологію і практику втілення соціальних інновацій у системи ПУ (Попов, 2017: 366). Ці напрацювання сприятимуть продукуванню якісної інформації (чинник - a), адекватного інструментарію для змістовно-якісного іiі опрацювання (чинник - b), наукових засад щодо побудови і реалізації МПД (чинник - c), засад професійної компетентності реформаторів (чинник $-\mathrm{d}) .3$ огляду на це правдоподібність політико-правового рішення щодо МПД можна охарактеризувати ймовірністю $\mathrm{D}=\mathrm{f}(\mathrm{a}, \mathrm{d}, \mathrm{c}, \mathrm{d})$ (Попов, 2017: 177). Найвищий рівень правдоподібності $\mathrm{D}$ можливий за умови, що D > Dп (Dп - порогове значення, яке задовольняє розробника). Якщо ж D $<$ Dп, то необхідно систематично повторювати пошук інформації і її опрацьовувати з метою посилення правдоподібності цього рішення. Таке розуміння є цілком прийнятним із позиції побудови образу ПМД, оскільки погляд (у часі) у віддалене майбутнє завжди супроводжується невизначеностями. Окрім того, їх поле доповнюється «просторовими» невизначеностями медичної галузі, які зумовлені ії територіальними відмінностями організаційної культури, ментальності, уподобань та ін., що стримує рух реформи і навіть може їі відхилити.

Відомими способами проектування образу майбутнього, які забезпечують зниження рівня невизначеностей, є прогнозні і форсайт дослідження. Порівнюючи їх, дослідники (Кравченко, 2015: 127; Квітка, 2018: 70; Садовник, 2016: 136; Рибінцев, 2017: 94; Філіппова, 2020: 15; Цедік, 2016: 100) вважають ФТ більш продуктивною, доводять переваги їі використання в ПУ через те, що: 
по-перше, ця технологія грунтується на використанні широкого спектра методів, здатних спроєктувати віддалене (на 10-20 років) майбутнє, передбачає розробку альтернативних варіантів розвитку, вироблення узгоджених конструктивних заходів із досягнення вибраних стратегічних напрямів, забезпечує оцінку можливих перспектив розвитку медичної галузі, визначення ймовірних соціально-економічних ефектів, можливих ризиків й упущеної економічної вигоди, передбачає систему раннього попередження негативних чинників, що є особливо цінним із точки зору виявлення факторів спротиву нововведенням;

по-друге, проєктування цього образу забезпечується системною роботою і комунікацією, активною і конструктивною дискусією широкого кола зацікавлених стейкхолдерів (експертів і науковців різного спрямування, представників влади, бізнесу і громадськості, зокрема професійних організацій). Така розширена участь $\epsilon$ цінною не тільки для проєктування образу МПД, а й з позиції забезпечення успішності її впровадження як способу соціалізації інноваційної ідеї, яка з часом стане «своєю».

ФТ нині утверджується в Україні, зокрема, відомими є форсайт економіки України на середньо- (20152020 рр.) і довгостроковий (2020-2030рр.) часові горизонти (Форсайт економіки України..., 2015: 24), регіональний форсайт розвитку людського капіталу (Кривцова, 2020: 60), де одним із ключових факторів є охорона здоров'я. Також відомими є форсайти розвитку людського капіталу України 2025 i впливу COVID19 на економіку і суспільство. Публічна влада зарубіжжя поширено використовує ФТ. Зокрема, у Великій Британії, Фінляндії утвердилися форсайт-програми, парламентські комітети майбутнього, відповідні інформаційно-аналітичні і державні структури, включаючи Департамент здоров'я, Національну службу охорони здоров’я, які забезпечують форсайт-підтримку діяльності уряду.

До недоліків ФТ дослідники зараховують значні фінансово-матеріальні витрати. Проте їх величина $\epsilon$ значно меншою, ніж втрати суспільства від значної затримки втілення медичної реформи. Інший недолік зумовлений відсутністю оцінювання правдоподібності (точності) передбачення, зокрема, щодо достовірності образу нової МПД. Цей недолік компенсують систематично повторювані форсайт-дослідження (даліФД), що й передбачає ФТ, нові знання про сутність образу майбутнього і шляхів його досягнення. Ці знання передусім мають сприяти оновленню вже застарілих засад МПД, що передбачено нормативно-правовими засадами внутрішньої і зовнішньої політики.

Форсайт зародився як спосіб технологічного прогнозування (Садовник, 2016: 136). Згодом ФТ застосували для прогнозування економік країн світу (Великої Британії, США, Німеччини, Ірландії, Японії, Китаю), iї окремих галузей (галузевий форсайт). У працях дослідників (Кравченко, 2015: 127; Квітка, 2018: 70; Садовник, 2016: 136; Рибінцев, 2017: 94; Філіппова, 2020: 15; Цедік, 2016: 100) розглянуто поняття «форсайт» (табл. 1). Їх аналіз за основними ознаками (форсайт-результат, форсайт-процес) дає змогу виявити предметне поле ФТ (табл. 2).

\section{Трактування поняття «форсайт»}

Таблиця 1

\begin{tabular}{|c|c|}
\hline Б. Мартін & $\begin{array}{l}\text { Форсайт - це систематичні спроби заглянути в довгострокове майбутнє розвитку науки, технології, } \\
\text { економіки і суспільства з метою визначити стратегічні галузі наукових досліджень і появу базових } \\
\text { технологій, від застосування яких можна очікувати найбільші економічні і соціальні вигоди. }\end{array}$ \\
\hline Й. Шварц & $\begin{array}{l}\text { Форсайт - це діяльність, спрямована на критичне мислення стосовно довгострокового розвитку, } \\
\text { проведення дискусій щодо такого розвитку задля створення широкої представницької демократії, } \\
\text { формування майбутнього шляхом впливу на державну політику. }\end{array}$ \\
\hline UNIDO & $\begin{array}{l}\text { Форсайт - це сценарне прогнозування соціально-економічного розвитку економіки, промисловості } \\
\text { та суспільства в 10-20-річній перспективі. }\end{array}$ \\
\hline EU FOREN Guide & $\begin{array}{l}\text { Форсайт - це систематичний, спільний процес побудови бачення майбутнього, націленого на } \\
\text { підвищення якості прийняття в цей момент рішень і прискорення спільних дій. Ідеологія форсайту } \\
\text { походить від конвергенції тенденції сучасних розробок в області політичного аналізу, стратегічного } \\
\text { аналізу та прогнозування. }\end{array}$ \\
\hline О. Сад & $\begin{array}{l}\text { Форсайт - це технологія, яка містить сукупність методів і засобів, що використовуються для } \\
\text { реалізації фахівцями складного процесу стратегічного передбачення шляхом поділу його на систему } \\
\text { послідовних взаємопов'язаних процедур і операцій, які мають на меті розробку концепції розвитку } \\
\text { окремого сегмента діяльності підприємства, галузі чи країни загалом у середньостроковому або } \\
\text { довгостроковому періоді. }\end{array}$ \\
\hline \multirow[t]{2}{*}{ С. Квітка } & $\begin{array}{l}\text { Форсайт - це спеціальна технологія формування пріоритетів розвитку різних сфер життя суспільства } \\
\text { з метою мобілізації максимально великої кількості учасників для досягнення якісно нових } \\
\text { результатів у розвитку країни, регіону, громади. }\end{array}$ \\
\hline & $\begin{array}{l}\text { Форсайт - це процес, метою якого є визначення можливого майбутнього, створення його бажаного } \\
\text { образу та визначення стратегій його досягнення. }\end{array}$ \\
\hline
\end{tabular}

Так, Т.А. Кравченко (Кравченко, 2015: 127) оспирається на поняття, сформульовані UNIDO і EU FOREN Guide, та стверджує, що основною метою застосування ФТ є підтримка прийняття стратегічних рішень (тобто, політико-правових рішень) шляхом розробки альтернативних сценаріїв розвитку. Аналіз поля дії ФТ (табл. 2) підтверджує доцільність її використання в ПУ, оскільки стосується, зокрема: бажаного образу і стратегії його досягнення; концепції розвитку галузі загалом у середньостроковому або довгостроковому періоді; майбутнє як спосіб підвищення якості прийняття теперішніх рішень і прискорення спільних дій. 
Нині ФТ розглядається як інструмент формування і реалізації державної політики, зокрема у сфері педагогічної освіти (Філіппова, 2020: 15).

Таблиця 2

Характеристика поняття «форсайт» за основними його ознаками

\begin{tabular}{|c|c|}
\hline \multirow[t]{7}{*}{ Форсайт-результат } & $\begin{array}{l}\text { Майбутні стратегічні галузі наукових досліджень і базових технології, які є перспективними для } \\
\text { отримання найбільших економічних і соціальних вигід }\end{array}$ \\
\hline & $\begin{array}{l}\text { Прогноз соціально-економічного розвитку економіки, промисловості та суспільства в 10-20-річній } \\
\text { перспективі }\end{array}$ \\
\hline & $\begin{array}{l}\text { Довгостроковий розвиток, широка представницька демократія, майбутнє, сформоване шляхом } \\
\text { впливу на державну політику }\end{array}$ \\
\hline & Майбутне як спосіб підвищення якості прийняття теперішніх рішень і прискорення спільних дій \\
\hline & $\begin{array}{l}\text { Концепція розвитку окремого сегменту діяльності підприємства, галузі чи країни загалом у } \\
\text { середньостроковому або довгостроковому періоді }\end{array}$ \\
\hline & Пріоритети розвитку різних сфер життя суспільства \\
\hline & Бажаний образ та стратегії його досягнення \\
\hline \multirow[t]{7}{*}{ Форсайт-процес } & $\begin{array}{l}\text { Систематичні спроби побачити майбутнє розвитку науки, технологій, економіки і суспільства } \\
\text { в довгостроковій перспективі }\end{array}$ \\
\hline & Сценарне прогнозування \\
\hline & Критичне мислення, проведення дискусій щодо довгострокового розвитку \\
\hline & Систематичний, спільний процес побудови бачення майбутнього \\
\hline & Технологічний процес стратегічного передбачення \\
\hline & $\begin{array}{l}\text { Процес формування пріоритетів розвитку шляхом мобілізації максимально великої кількості } \\
\text { учасників }\end{array}$ \\
\hline & Процес визначення можливого майбутнього, створення його бажаного образу \\
\hline
\end{tabular}

Форсайт-методологія (далі - ФМ) окреслює функції (табл. 2 і 3) і сукупність методів (Кравченко, 2015: 127), (Квітка, 2018: 70). Функції ФМ аналізує (Садовник, 2016: 136) в межах «ромбу форсайту» і його доповнює сучасною функцією у складі «п'ятикутника форсайту»: креативність (генерування ідей), експертиза (експертні оцінки), взаємодія (експертів у прийнятті ключових рішень), достовірність (верифікація форсайт-ідей) і керованість (керування кластерами проектів). Перелік цих функцій можна уточнити, розширити, спираючись на загальну методологію досліджень і конкретні завдання форсайту.

Таблиця 3

\section{Особливості форсайт-методології}

\begin{tabular}{|l|l|}
\hline Форсайт методи & Обмежено використовуються методи кількісних оцінок \\
\cline { 2 - 3 } & $\begin{array}{l}\text { Поширено використовуються методи експертних оцінок: метод Дельфі, визначення критичних } \\
\text { технологій, розробка сценаріїв, зворотне сценарування, експертні панелі, розробка майбутнього; } \\
\text { аналіз глобальних трендів; мультикритерійний аналіз; аналіз взаємних впливів; SWOT-аналіз; } \\
\text { екстраполяція трендів; картування технологій; картування стейкхолдерів; суспільні панелі; } \\
\text { моделювання і симуляція; мозковий штурм; виділення ключових технологій; матриця варіантів, } \\
\text { проведення конференцій, багатокритеріальне оцінювання, бенчмаркінг; випробовування; ігри; } \\
\text { огляд джерел, сканування джерел, бібліографічний аналіз, ін. (С. Квітка, Т. Кравченк). }\end{array}$ \\
\hline Функції ФТ & $\begin{array}{l}\text { Ромб функцій: «креативність (генерування форсайт ідей) - експертиза (перевірка цих ідей } \\
\text { на відповідність встановленим вимогам) - взаємодія (спільне прийняття ключових рішень } \\
\text { експертами) - достовірність (верифікація форсайт-напрацювань)». }\end{array}$ \\
\hline $\begin{array}{l}\text { Ідеологія } \\
\text { ФТ в ПУА }\end{array}$ & $\begin{array}{l}\text { Заснована на конвергенції тенденцій сучасних розробок в області політичного аналізу, } \\
\text { стратегічного аналізу та прогнозування }\end{array}$ \\
\hline Особливості ФТ у ПУА & $\begin{array}{l}\text { 1) комплексна взаємодія науки, технології та суспільства не лише як мислення, розмірковування } \\
\text { про майбутнє, а й дискурс про нього і його творення; } \\
\text { 2) здійснення більш ефективного вибору з можливих варіантів майбутнього; } \\
\text { 3) конфлікт висновків щодо розвитку науки й технологій із громадською думкою з позиції } \\
\text { відповідності можливостей науки суспільним потребам }\end{array}$ \\
\hline
\end{tabular}

У межах предмета цього дослідження доцільно: ФТ розглядати як галузевий форсайт; сформулювати поняття «форсайт» - як спосіб експертної підтримки прийняття довгострокових (на 10-20 років) політико-правових рішень, заснований на систематичному, активному, критичному і широкоформатному дискурсі, використанні продуктивних методів пізнання образу майбутнього. Особливість прийняття цього рішення полягає в тому, що воно законодавчо унормує нині один із сценаріїв розвитку, згідно з яким має сформуватися майбутнє.

Відомими є підходи до структурування і змістовного наповнення форсайт-дослідження (далі - ФД), зокрема, прикладами є форсайт економіки України (Форсайт економіки України..., 2015: 24), напрямів розвитку науки і техніки України (Кизим, 2015: 99), розвитку людського потенціалу регіону (Кривцова, 2020: 60). 
На різноманіття підходів до проведення ФД вказує (Рибінцев, 2017: 94) і стверджує, що поширеним $\epsilon$ триетапне дослідження, яке реалізує три функції ФМ: «креативність», «експертиза» $i$ «взаємодія». Оберемо цей підхід до формування образу МПД, доповнивши його четвертим етапом ФД (табл. 4) для реалізації додаткової функції «достовірність», спрямованої на верифікацію результатів цього дослідження.

На організаційному етапі необхідно виконати завдання за вказаними стадіями (табл. 4). При цьому визначитися з ймовірним комплексом методів, враховуючи їх тип і функціональне призначення. можливими витратами з бюджету держави та інших джерел фінансування, масштабом і рівнем охоплення ФД (стосується усього простору медичної галузі), горизонтом дослідження - мінімум 10 років, колом осіб, що забезпечать політичну, владну (уряд, міністерство охорони здоров’я) і фінансову підтримку цього ФД.

Процес форсайт-технології в публічному управлінні медичною політикою держави

Таблиця 4

\begin{tabular}{|l|l|l|l|}
\hline \multicolumn{1}{|c|}{$\begin{array}{c}\text { Організаційний } \\
\text { етап }\end{array}$} & \multicolumn{1}{c|}{$\begin{array}{c}\text { Етап формування } \\
\text { експертного середовища }\end{array}$} & \multicolumn{1}{c|}{$\begin{array}{c}\text { Етап здійснення } \\
\text { форсайту }\end{array}$} & $\begin{array}{c}\text { Етап підтвердження } \\
\text { достовірності (верифікації) }\end{array}$ \\
\hline 1) Постановка гіпотези ФД & 1) Підбір ключових акторів & 1) Проведення дослідження & $\begin{array}{l}\text { 1) Формування експертного } \\
\text { середовища }\end{array}$ \\
\hline $\begin{array}{l}\text { 2) Формування цілей } \\
\text { і завдань проекту }\end{array}$ & 2) Підбір експертних груп & $\begin{array}{l}\text { 2) Аналіз проблем, тенденцій, } \\
\text { взаємовпливу рушійних сил }\end{array}$ & 2) Експертне опитування \\
\hline 3) Вироблення плану роботи & & $\begin{array}{l}\text { 3) Формування варіантів } \\
\text { майбутнього або пропозиції } \\
\text { щодо бажаних його варіантів }\end{array}$ & $\begin{array}{l}\text { 3) Проведення фокус- } \\
\text { iнтерв’ю }\end{array}$ \\
\hline $\begin{array}{l}\text { 4) Формування очікуваних } \\
\text { наслідків }\end{array}$ & $\begin{array}{l}\text { 4) Проведення інтерв’ю } \\
\text { «компетентний експерт» }\end{array}$ \\
\hline
\end{tabular}

На етапі формування експертного середовища (табл. 4) необхідно, виходячи з вибраного комплексу ефективних методів, визначитися з колом досвідчених ключових осіб (передусім від публічної влади, закладів О3, громадських організацій) і експертних груп із конкретних питань МПД, до яких залучити представників органів ПУ, медичних закладів і громадських інституцій, бізнесу тощо, а також врахувати рівень розробленості МПД до започаткування ФД.

На третьому (дослідницькому) етапі (табл. 4) необхідно на першій стадії виявити поле проблем, важливі тенденції і напрями ФД із використанням методів аналізу літератури і мозкового штурму, на другій стадіï - проаналізувати основні проблеми, тенденції та взаємовплив рушійних сил за використанням методів експертних панелей, екстраполяції трендів або SWOT-аналізу, на третій стадї - сформувати можливі або запропонувати бажані варіанти образу майбутньої МПД за використанням методів сценаріїв або Дельфі.

На етапі (верифікації) підтвердження достовірності необхідно на (табл. 4) першій стадї̈ сформувати коло експертів, спроможних оцінити достовірність проєкт образу МПД, на другій стадії - провести експертне опитування, опрацювати і узагальнити його результати і виявити найбільш підготовлених експертів, на третій стадіï - провести фокус-інтерв'ю з найбільш підготовленими експертами і обрати 3 них найбільш компетентного експерта, на четвертій стадії- провести інтерв'ю «компетентний експерт».

3 огляду на вищезазначене головними підсумками $є$ такі: 1) ціллю ФД і їі результатом має бути змістовне наповнення всіх складників образу МПД; 2) кращий результат ФД можна досягти шляхом поєднання більш продуктивних методів і вибору найбільш досвідчених експертів. Попередньо можна вибрати основним (на третій стадії третього етапу ФД) метод сценаріїв, який, спираючись на матрицю комбінації методів ФД (Рибінцев, 2017: 94), доповнити методами моделювання, інтерв'ю, мозкового штурму, SWOT-аналізу тощо.

Наведені вище судження лише узагальнено характеризують процес ФД. Для зменшення рівня невизначеностей доцільно його конкретизувати за складниками МПД (рис. 1). Для цього використаємо напрацювання вчених (Дослідження державних політик..., 2018: 245; Вошко, 2020: 334; Кравченко, 2008: 296; Попов, 2017: 366). Зазначимо, що головним у складі МПД є образ нової СО3, який сформуємо шляхом проведення ФД1 (рис. 1).

Цей образ $є$ надто складною соціальною інновацією, яка є запозиченою, вона переформатує всю медичну галузь. Загалом впровадження інновації, а особливо соціальної інновації, завжди породжує невизначеності високого рівня. Образ майбутньої СО3 має бути сформованим на етапі розробки МПД (Вошко, 2020: 334), комплексним і включати основні і додаткові принципово важливі складові, що забезпечать її повноцінне функціонування, врахувати основні позитивні риси, які нині відомі з вітчизняної реформаторської практики. Також необхідно подолати невизначеності, пов'язані із визначенням потреб і перспектив розвитку вітчизняної медичної галузі, включаючи сучасні технології, забезпеченням конкурентності СО3, якості надання МД, їх доступності в просторі країни і оплати МД, зокрема з врахуванням страхових внесків і участі роботодавців тощо. Необхідно завчасно виявити і вирішити можливі проблеми в процесі впровадження нової СО3, оскільки обов'язково постане питання про її адаптування до реалій медичної галузі. Оскільки нововведення (образ нової СО3) забезпечується інноваційною діяльністю (Попов, 2017: 97), то структурування підвищить рівень іiі розуміння, додатково зменшить рівень невизначеності при проведенні ФД. Для структурування цієї діяльності використаємо системно-діяльнісний метод, який дає їй змогу постати відкритою системою, яка взаємозв'язує основні її зовнішні і внутрішні складники. До останніх належать процес нововведення, управлінський процес, ресурси і основні види та способи супроводу. Вітчизняний досвід медичної реформи 


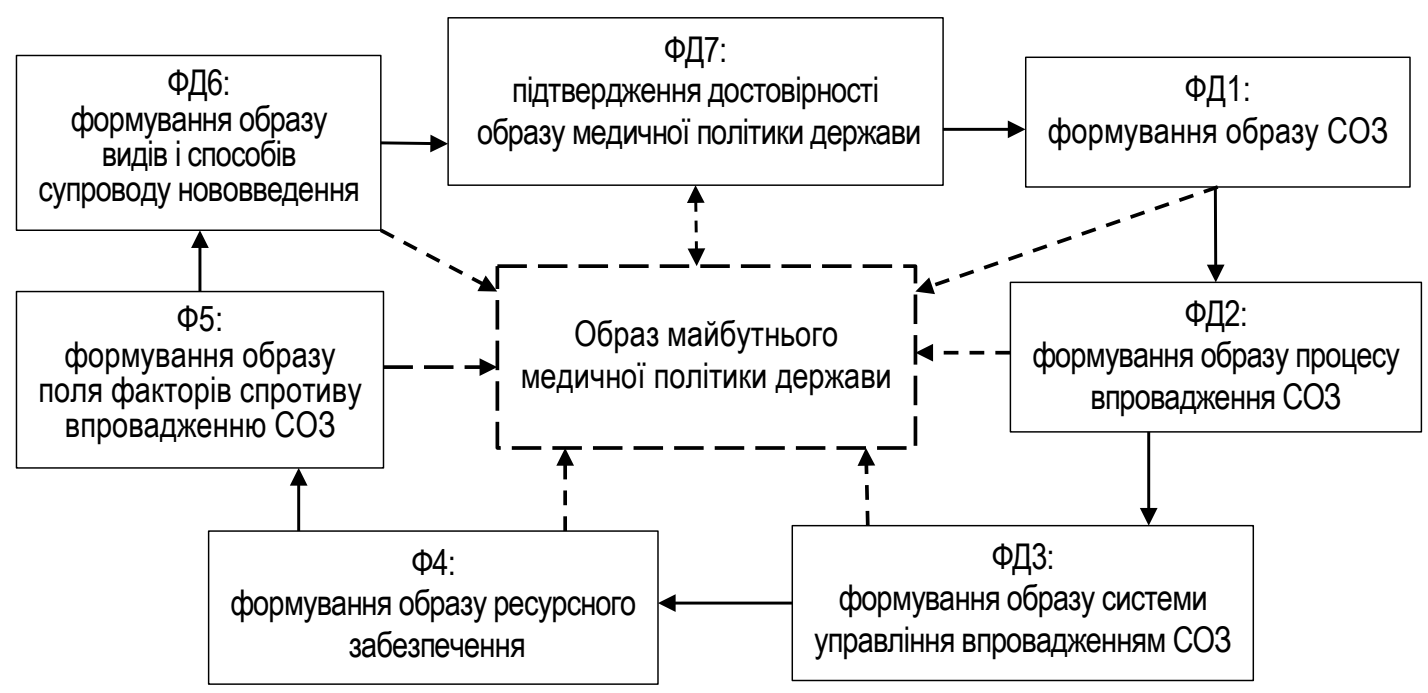

Рис. 1. Складники процесу форсайт-дослідження медичної політики держави

свідчить про поетапне впровадження кожного з видів МД. Процес їх впровадження є завжди оригінальним, поєднує процес поширення видів МД у просторі медичної галузі і інноваційні процеси в конкретному закладі О3. Іноді ці процеси складно структурувати, вони здійснюється ітеративним шляхом, методом спроб і помилок. Тому для подолання невизначеностей необхідно провести ФД2. Окрім того, на етапі розробки МПД необхідними є ще й інші ФД (рис. 1):

ФД3 стосується обгрунтованого конструювання системи управління зазначеними вище процесами в умовах слабко структурованої ситуації. Для цієї ситуації (Ансофф, 1989: 238) рекомендує використати методи стратегічного менеджменту. Тому головним для ФДз є конструювання раціональної системи управління процесами нововведень у медичній галузі;

ФД4 стосується визначення обсягу і якості ресурсів, де поряд з іншим (матеріально-фінансовим, інформаційно-методичним і науко-дослідним забезпеченням тощо) найвагомішою є професійна компетентність реформаторів, яка має грунтуватися на освітньому стандарті, підгрунтям для розробки якого є професійний стандарт. Иого розробка є трудомісткою, слабко визначеною і потребує додаткового форсайт-дослідження;

ФД5 стосується виявлення поля можливих факторів спротиву нововведенню для визначення 3 них найбільш загрозливих із метою їх завчасного подолання або пом'якшення;

ФД6 стосується визначення наявних у медичній галузі основних видів і способів супроводу процесу нововведень щодо навчання, комунікації, досліджень, методологічного і технологічного забезпечення, формування реформаторської культури. Незнання їх наявності і потреб у них також зумовить невизначеності. Якщо вони і є, то який їх наявний стан, обсяг і якість, якою є їх придатність до використання, яким чином компенсувати їх нестачу ззовні.

Поєднання результатів кожної із зазначених ФД має сформувати загальний образ майбутньої МПД. Завершальним дослідженням має бути доказове ФД7 (рис. 1), спрямоване на верифікацію отриманого результату шляхом доведення його достовірності (правдоподібності) за спеціальною методикою. Вона має поєднати методи опитування, фокус-інтерв'ю, інтерв'ю «компетентний експерт» (Попов, 2017: 270). Доказовість політики держави є новим напрямом у ПУ і розуміється (Дослідження державних політик..., 2018: 214) як доведена практикою і дослідженнями їі ефективність, доцільність і корисність; доказова методологія впровадження політики. Доказове ФД7 має передбачити грунтовне опрацювання МПД. У процесі постановки проблеми, на вирішення якої спрямована ця політика, необхідно відповісти на питання: чому це є проблемою? в яких країнах і яких контекстах вона є проблемою, а в яких на неї не звертають увагу? Під час розробки можливих заходів відповісти на питання: де і як над цією проблемою працювали ? якими $є$ успішні приклади розв’язання цієї проблеми? які заходи виявилися ефективними, а які - ні і чому?

Висновки. Теперішня реформа системи охорони здоров'я в Україні актуалізована низкою нормативноправових актів, має першорядне значення в належному збереженні, функціонуванні і розвитку суспільства. Проте за часів незалежності України ця реформа здійснюється стримано. Останнім часом отримано певні здобутки. Однак відставання від країн СНГ становить майже 20 років. Головні фактори спротиву зумовлені, передусім, відсутністю унормованої Державної медичної політики, принциповим протиріччям механізму формування і реалізації державної політики охорони здоров'я (затверджений основами законодавства України про охорону здоров’я) єдиному унормованому загальнодержавному механізму управління політикою держави, слабкою ефективністю програмно-цільового управління реформою в умовах невизначеностей високого рівня тощо.

Для змістовного наповнення образу концепції Державної медичної політики в умовах невизначеності вибрано і обгрунтовано чотириетапну форсайт-технологію, яка реалізує функції креативність, експертиза, взаємодія і достовірність. Для зменшення рівня невизначеності пропонується структурувати 
форсайт-дослідження на 7 складників, спираючись на сучасні знання про урядові реформи, соціальні інновації, інноваційну діяльність у публічному управлінні і доказову державну політику. Результати цих досліджень сумісно сформують образ майбутньої медичної політики. Сьоме дослідження має забезпечити підтвердження достовірності (верифікацію) цього образу за використанням доказової методики.

Наведені вище судження є загальними і потребують подальшої конкретизації форсайт-дослідження, зокрема, щодо вибору і апробації продуктивних методів і визначення експертного середовища.

\section{Список використаних джерел:}

1. Ансофф И. Стратегическое управление / пер. с англ. Москва : Экономика, 1989. 519 с.

2. Вошко І.В. Сучасні засади державної медичної політики: стратегічний підхід. Право та державне управління. 2020. № 2. C. 326-334. DOI: https://doi.org/10.32840/pdu.2020.2.49.

3. Дослідження державних політик: методологія, процедури та європейські практики : монографія / авт. кол. : Л.В. Гонюкова, В.М. Козаков, В.А. Ребкало та ін.; за заг. ред. Л.В. Гонюкової, В.М. Козакова. Київ : НАДУ, 2018. 400 с.

4. Квітка С.А. Форсайт в публічному управлінні: методи і перспективи реалізації в Україні. Аспекти публічного управління. 2018. Вип. Т. 6. № 8. С. 56-70. DOI: 10.15421/151847.

5. Кизим М.О. Перспективи форсайт-прогнозування пріоритетних напрямів розвитку нанотехнологій i наноматеріалів у країнах світу і Україні : монографія / М.О. Кизим, І.Ю. Матюшенко, І.В. Шостак, М.О. Данова. Харків : ВД «IНЖЕК», 2015. $272 \mathrm{c}$.

6. Кравченко С.О. Державно-управлінські реформи: теоретико-методологічне обгрунтування та напрями впровадження [Текст] : монографія. Київ : НАДУ, 2008. 296 с.

7. Кравченко Т.А. Доцільність використання методології форсайту при розробці Єдиної комплексної стратегії розвитку сільського господарства та сільських територій на 2015-2020рp. Аспекти публічного управління. 2015. Вип. 4(18). С. 121-128.

8. Кривцова М.С. Використання форсайт-технології у стратегічному прогнозуванні розвитку людського потенціалу регіону. Вісник сочіально-економічних досліджень. 2020. Вип. № 2 (73). С. 47-60.

9. Попов С.А. Інноваційний розвиток системи органів публічної влади: стратегічний підхід : монографія. Одеса : ОРІДУ НАДУ, 2017. $368 \mathrm{c}$.

10. Рибінцев В.О. Форсайт як технологія реалізації стратегії розвитку економіки / В.О. Рибінцев, І.О. Клопов. Інтелект XXI. 2017. № 3. С. 87-94. URL: http://nbuv.gov.ua/UJRN/int XXI 2017314.

11. Садовник О.В. Розвиток форсайту та його вплив на прогнозування продуктово-ринкової стратегії агробізнесу в України. Стратегія економічного розвитку. 2016. Вип. № 39. С. 126-135.

12. Філіппова В.Д. Форсайт-технологія як інструмент формування і реалізації державної політики в галузі педагогічної освіти. Теорія та практика державного управління $і$ місцевого самоврядування. 2020. Вип. № 1. DOI: https://doi.org/10.35546/kntu2308-8834/2020.1.28.

13. Форсайт економіки України: середньостроковий (2015 - 2020 роки) і довгостроковий (2020-2030 роки) часові горизонти / наук. керівник проекту акад. НАН України М.З. Згуровський. Міжнародна рада з науки (ICSU); Комітет із системного аналізу при Президії НАН України; Національний технічний університет України «Київський політехнічний інститут»; Інститут прикладного системного аналізу НАН України і МОН України; Світовий центр даних 3 геоінформатики та сталого розвитку. 2015. $136 \mathrm{c}$.

14. Цедік М.Г. Визначення перспектив застосування регіонального форсайту в системі публічного управління України. Аспекти публічного управління : зб. наук. пр. ДРІДУ. 2016. Вип. № 3(29). С. 94-100.

\section{References:}

1. Ansof, Y. (1989). Stratehycheskoe upravlenye [Strategic management] : per. s anhl. M. : Ekonomyka. $519 \mathrm{~s}$.

2. Voshko, I.V. (2020). Suchasni zasady derzhavnoi medychnoi polityky: stratehichnyi pidkhid [Modern principles of state medical policy: a strategic approach]. Pravo ta derzhavne upravlinnia. № 2. DOI https://doi.org/10.32840/pdu.2020.2.49 [in Ukrainian].

3. Honiukova, L.V. (2018). Doslidzhennia derzhavnykh polityk: metodolohiia, protsedury ta yevropeiski praktyky [Public policy research: methodology, procedures and European practices] : monohrafiia / avt. kol. : L.V. Honiukova, V.M. Kozakov, V.A. Rebkalo ta in. ; za zah. red. L.V. Honiukovoi, V.M. Kozakova. Kyiv : NADU, 2018. $400 \mathrm{~s}$ [in Ukrainian].

4. Kvitka, S.A. (2018). Forsait v publichnomu upravlinni: metody i perspektyvy realizatsii v Ukraini [Foresight in Public Administration: Methods and Perspectives of Implementation in Ukraine]. Public administration aspects, Vyp. T. 6. № 8. S. 56-70. DOI: 10.15421/151847 [in Ukrainian].

5. Kizim, M.O. (2015). Perspektyvy forsait-prohnozuvannia priorytetnykh napriamiv rozvytku nanotekhnolohii i nanomaterialiv u krainakh svitu i Ukraini [Prospects for foresight forecasting of priority areas of nanotechnology and nanomaterials development in the countries of the world and Ukraine] : monohrafiia / M.O. Kyzym, I.Yu. Matiushenko, I.V. Shostak, M.O. Danova. Kh. : VD «INZhEK». $272 \mathrm{~s}$ [in Ukrainian].

6. Kravchenko, S.O. (2008). Derzhavno-upravlinski reformy: teoretyko-metodolohichne obgruntuvannia ta napriamy vprovadzhennia [Public administration reforms: theoretical and methodological substantiation and directions of implementation] [Tekst] : monohrafiia. K. : NADU, 2008. $296 \mathrm{~s}$ [in Ukrainian].

7. Kravchenko, T.A. (2015) Dotsilnist vykorystannia metodolohii forsaitu pry rozrobtsi Yedynoi kompleksnoi stratehii rozvytku silskoho hospodarstva ta silskykh terytorii na 2015-2020 rr [Expediency of using the foresight methodology in the development of the Unified Comprehensive Strategy for the Development of Agriculture and Rural Areas for 2015-2020]. Aspekty publichnoho upravlinnia. Vyp. 4(18). S. 121-128 [in Ukrainian]. 
8. Kryvtsova, M.S. (2020). Vykorystannia forsait-tekhnolohii u stratehichnomu prohnozuvanni rozvytku liudskoho potentsialu rehionu [Foresight technology using in the strategic forecasting of human potential development of the region]. Visnyk sotsialno-ekonomichnykh doslidzhen. 2020. Vyp. № 2 (73). S. 47-60 [in Ukrainian].

9. Popov, S.A. (2017). Innovatsiinyi rozvytok systemy orhaniv publichnoi vlady: stratehichnyi pidkhid [Innovative development of the system of public authorities: a strategic approach]. Monohrafiia. $368 \mathrm{~s}$ [in Ukrainian].

10. Rybintsev, V.O. (2017). Forsait yak tekhnolohiia realizatsii stratehii rozvytku ekonomiky [Foresight as a technology for implementing the strategy of economic development]. Intelekt XXI. Vyp. № 3. S. 87-94 [in Ukrainian].

11. Sadovnyk, O.V. (2016). Rozvytok forsaitu ta yoho vplyv na prohnozuvannia produktovo-rynkovoi stratehii ahrobiznesu $\mathrm{v}$ Ukrainy [Development of foresight and its impact on forecasting the product and market strategy of agribusiness in Ukraine]. Stratehiia ekonomichnoho rozvytku. Vyp. № 39. S. 126-135 [in Ukrainian].

12. Filippova, V.D. (2020). Forsait-tekhnolohiia yak instrument formuvannia i realizatsii derzhavnoi polityky v haluzi pedahohichnoi osvity [Foresight technology as a tool for the formation and implementation of state policy in the field of teacher education]. Teoriia ta praktyka derzhavnoho upravlinnia i mistsevoho samovriaduvannia. Vyp. № 1. DOI: https:// doi.org/10.35546/kntu2308-8834/2020.1.28 [in Ukrainian].

13. Forsait ekonomiky Ukrainy: serednostrokovyi (2015-2020 roky) i dovhostrokovyi (2020-2030 roky) chasovi horyzonty [Foresight of Ukraine's economy: medium-term (2015-2020) and long-term (2020-2030) time horizons] / nauk. kerivnyk proektu akad. NAN Ukrainy M. Z. Zghurovskyi. Mizhnarodna rada z nauky (ICSU); Komitet iz systemnoho analizu pry Prezydii NAN Ukrainy; Natsionalnyi tekhnichnyi universytet Ukrainy «Kyivskyi politekhnichnyi instytut»; Instytut prykladnoho systemnoho analizu NAN Ukrainy i MON Ukrainy; Svitovyi tsentr danykh z heoinformatyky ta staloho rozvytku. 2015. $136 \mathrm{~s}$ [in Ukrainian].

14. Tsedik, M.H. (2016). Vyznachennia perspektyv zastosuvannia rehionalnoho forsaitu v systemi publichnoho upravlinnia Ukrainy [Determining the prospects for the use of regional foresight in the system of public administration of Ukraine]. Aspekty publichnoho upravlinnia : zb. nauk. pr. DRIDU, vyp. № 3(29). Dnipropetrovsk DRIDU NADU. S. 94-100 [in Ukrainian]. 